\title{
FREQUÊNCIA DE ANTICORPOS ANTI-Neospora caninum EM VACAS E FETOS PROVENIENTES DE MUNICÍPIOS DO SUL DE MINAS GERAIS*
}

\author{
MARLON H. PAIVA GUEDES ${ }^{1}$; ANTÔNIO M. GUIMARÃES²; CHRISTIANE M.B.M. ROCHA ${ }^{2}$; CHRISTIAN HIRSCH²
}

\begin{abstract}
GUEDES, M.H.P.; GUIMARÃES, A.M.; ROCHA, C.M.B.M.; HIRSCH, C. [Frequency of antiNeospora caninum antibodies in cows and fetuses from Municipalities of Southern Minas Gerais]. Freqüência de anticorpos anti-Neospora caninum em vacas e fetos provenientes de municípios do sul de Minas Gerais. Revista Brasileira de Parasitologia Veterinária, v. 17, n. 4, p. 189-194, 2008. Departamento de Medicina Veterinária, Universidade Federal de Lavras, Caixa Postal 3037, Lavras, MG. 37200-000, Brasil. E-email: amg@ufla.br

The objective of this study was to determine the frequency of antibodies anti-Neospora caninum in cows and fetuses from Municipalities of southern Minas Gerais. A total of 559 serum samples of cows of the a bank of sera formed from of serum samples collected at 18 dairy farms, distributed for seven Municipalities of the Lavras Micro region, southern Minas Gerais, and 575 serum samples of cows and 503 serum samples of fetuses were collected at slaughter house of Campo Belo, MG. Serum samples were submitted to the indirect fluorescent antibody tests (IFAT), using as antigen taquizoites of $N$. caninum, and as cut-off values the serum dilution of 1:25 for the fetuses serum and 1:200 for the cows. The frequency in the cows of the Lavras Micro region was of $91.2 \%$ (510/559). The frequency was of 97.2\% (559/575) and 12.7\% (64/503) for females and fetuses from slaughter house, respectively. These results indicate that the infection by $N$. caninum is endemic in dairy cattle of the Lavras Micro region, southern Minas Gerais, Brazil.
\end{abstract}

KEY WORDS: Neosporosis, bovine, congenital transmission, fluorescent antibody.

\section{RESUMO}

O objetivo deste estudo foi determinar a freqüência de anticorpos anti-Neospora caninum em vacas e fetos provenientes de municípios do sul de Minas Gerais. Foram utilizadas 559 amostras de soros de vacas de um banco de soros formado a partir de amostras coletadas em 18 propriedades produtoras de leite, distribuídas por sete municípios da microrregião de Lavras, MG; e 575 amostras de soros de vacas e 503 de soros fetais, ambas coletadas no matadouro de Campo Belo, MG. As amostras foram submetidas à reação de imunofluorescência indireta (RIFI-IgG), para pesquisa de anticorpos anti- $N$. caninum, considerando como ponto de corte o título de 1:200 para as fêmeas bovinas e 1:25 para os soros fetais. A freqüência média global de anticorpos anti- $N$. caninum em vacas leiteiras das fazendas da microrregião de Lavras foi de 91,2\% (510/559) e nas vacas abatidas em matadouro e fetos de $97,2 \%$

\footnotetext{
* Sob os auspícios da FAPEMIG.

${ }^{1}$ Curso de Pós-Graduação em Ciências Veterinárias, Universidade Federal de Lavras (UFLA), Lavras, MG.

${ }^{2}$ Departamento de Medicina Veterinária, UFLA, Campus Universitário, Caixa Postal nº 3037, Lavras, MG. 37200-000, Brasil. E-mail: amg@ufla.br
}

(559/575) e 12,7\% (64/503), respectivamente. Esses resultados indicam que a infecção por $N$. caninum está amplamente distribuída em rebanhos leiteiros da microrregião de Lavras, sul de Minas Gerais.

PALAVRAS-CHAVE: Neosporose, bovino, transmissão congênita, anticorpos fluorescentes.

\section{INTRODUÇÃO}

Neosporose bovina é uma doença parasitária causada pelo protozoário Neospora caninum (DUBEY et al., 1988). Essa enfermidade é considerada como uma das principais causas de aborto em bovinos em todo o mundo, sendo responsável por expressivos prejuízos econômicos a rebanhos de corte e, especialmente, a pecuária leiteira (DUBEY; LINDSAY, 1996).

A presença de bovinos infectados com $N$. caninum tem sido relatada em países da América do Norte, Europa, Ásia, África e Oceania (DUBEY, 1999). Na América do Sul, rebanhos positivos para $N$. caninum foram notificados na Argentina, Brasil, Chile, Paraguai, Peru, Uruguai e Venezuela (MOORE, 2005). A prevalência de anticorpos anti- $N$. caninum em bovinos leiteiros pode ser muito alta, chegando até a $100 \%$ em certos rebanhos (DUBEY; SCHARES, 2006). 
A infecção congênita ou vertical é considerada a principal via de transmissão para os bovinos (DAVISON et al., 1999). A transmissão horizontal, que ocorre por ingestão de oocistos esporulados presentes no ambiente, é considerada como rota secundária da infecção (DUBEY, 1999).

Diferentes estudos com bovino de corte ou de leite têm procurado identificar os fatores de risco envolvidos na maior freqüência de anticorpos anti- $N$. caninum nos rebanhos. Dentre esses fatores de risco se destacam, principalmente, os relacionados ao manejo do rebanho (intensivo ou extensivo), a idade dos bovinos e a presença de cães na propriedade (CORBELLINI et al., 2006).

A região sul de Minas Gerais se destaca como uma das principais bacias leiteiras do país, abastecendo grandes centros como São Paulo, além de fornecer matéria prima para as indústrias de laticínios localizadas no próprio Estado. Devido à ausência de informações sobre a epidemiologia da neosporose bovina nas localidades estudadas, o principal objetivo deste estudo foi determinar a freqüência de anticorpos anti- $N$. caninum em 18 propriedades leiteiras localizadas em sete municípios da microrregião de Lavras, MG; e em amostras de soros coletados de vacas e fetos em matadouro do município de Campo Belo, sul de Minas Gerais.

\section{MATERIAL E MÉTODOS}

Caracterização da área de estudo. A microrregião de Lavras se caracteriza como um importante pólo de produção de leite no Sul de Minas Gerais, com um total de 45.000 vacas em ordenha e uma produção média de 112.366 .000 litros de leite por ano (IBGE, 2004). Possui um clima tipo Cwa, temperado de altitude, segundo a classificação de KOPPEN, com duas estações bem definidas durante o ano (ANTUNES, 1986). A estação chuvosa, geralmente começa em outubro e se estende até março, e o período seco compreendido entre os meses de abril a setembro.

Amostra do estudo 1 - propriedades leiteiras da microrregião de Lavras. Um banco de soros, coletados no período de janeiro a março de 2004 em 18 fazendas, foi utilizado. As propriedades foram visitadas uma única vez cada, produziam leite tipo B ou C e estavam distribuídas por sete municípios desta microrregião. Para caracterizá-las, quando da coleta das amostras de soros, foram aplicadas entrevistas aos produtores para obtenção de dados sobre suas principais características (Tabelas 1 e 2).

Para a condução deste estudo foram selecionadas todas as 559 amostras de soros de vacas disponíveis no banco de soros, devido à grande possibilidade de associação entre $N$. caninum e distúrbios reprodutivos, como abortos. Essas vacas estavam distribuídas em 18 propriedades localizadas nos municípios de Carrancas, Ijaci, Ingaí, Lavras, Luminárias, Nepomuceno, e Ribeirão Vermelho. As propriedades foram divididas em dois grupos de acordo com a produção diária de leite: A) oito fazendas com uma produção abaixo de 1.000 litros de leite/dia, e B) dez fazendas com uma produção acima de 1.000 litros de leite/dia.
Amostra do estudo 2 - soros de vacas e de fetos coletados em matadouro. As amostras foram coletadas em um matadouro com Serviço de Inspeção Federal, no município de Campo Belo, sul de Minas Gerais, no período de janeiro a maio de 2006. Com o intuito de manter a mesma proporcionalidade com o número de amostras de soros de vacas analisadas no estudo 1 $(n=559)$, foram coletadas 575 amostras de soros de vacas mestiças, descartadas de fazendas produtoras de leite localizadas em oito municípios do sul de Minas Gerais (Boa Esperança, Campo Belo, Campos Gerais, Carvalhos, Cordislândia, Ilicínea, Nepomuceno, e Três Corações). Como na amostra do estudo 1, também só foi coletado sangue de vacas, pela possibilidade de associação entre $N$. caninum e distúrbios reprodutivos ${ }^{3}$.

As amostras de sangue ( $5 \mathrm{ml}$ ) foram coletadas em tubos de ensaio de $10 \mathrm{ml}$, sem anticoagulante, na linha de abate, durante a sangria de vacas com variado grau de mestiçagem de holandês com zebu. Para manter a mesma proporção de amostras coletadas de vacas descartadas, foram também coletadas 503 amostras de sangue ( $3 \mathrm{ml}$ ) em tubos de ensaio de $10 \mathrm{ml}$, sem anticoagulante, de fetos oriundos de vacas prenhas abatidas no matadouro de Campo Belo. Durante a evisceração e após a abertura da placenta foi coletado o sangue pelo cordão umbilical e então mensurado o comprimento da coluna vertebral dos fetos, a partir da articulação atlanto-occipital até o final do sacro, para determinação de suas idades, conforme recomendado por Roberts (1984).

As amostras de sangue das vacas e dos fetos foram centrifugadas a $3.500 \mathrm{rpm}$ por 10 minutos para obtenção do soro. Posteriormente, os soros foram acondicionados em criotubos com capacidade de $2 \mathrm{ml}$ e mantidos a $-20^{\circ} \mathrm{C}$ até realização da sorologia.

Sorologia. A reação de imunofluorescência indireta (RIFI) foi realizada conforme técnica descrita por Madruga et al. (2001) no Laboratório do Departamento de Medicina Veterinária da Universidade Federal de Lavras (UFLA), utilizando como antígeno lâminas adquiridas do Laboratório Imunodot (Jaboticabal, SP). Conjugado anti-IgG bovino (Sigma Chemical) foi utilizado na diluição 1:300 em PBS-Tween 20. Foi considerado positivo (cut off) o soro que apresentou título na diluição 1:200 para vacas e 1:25 para os fetos, e com completa fluorescência da superfície dos taquizoítos de $N$. caninum (DUBEY; SCHARES, 2006). As amostras de soros fetais positivas foram novamente examinadas em diluições seqüenciais na base dois até 1:3.200.

Análise estatística. Para a análise foi formado um banco de dados no programa EPIDATA 3.1. As análises descritivas de todas as variáveis deste estudo foram realizadas no programa SPSS 12.0 for Windows. Em seguida, analisou-se a associação entre níveis de freqüência de $N$. caninum nos rebanhos e as variáveis consideradas como fatores de risco (área da propriedade, tamanho do rebanho, produção leiteira, intervalo médio de partos, e histórico de aborto) por meio do Teste Exato de Fisher. Testou-se também a associação dos fatores

${ }^{3}$ IMA. Divisão de Defesa Sanitária Animal. Comunicação pessoal. 2006. 
de risco mencionados anteriormente com a freqüência acima e abaixo de $95 \%$ das vacas soropositivas. Para testar a diferença de médias foi utilizado o teste t de Student, testando-se a igualdade de variâncias. Para todos os cálculos considerouse a grau de significância de 95\%.

\section{RESULTADOS}

Caracterização das propriedades leiteiras da microrregião de Lavras. Nas Tabelas 1 e 2 observam-se as características das propriedades dos grupos A e B. Os valores de

Tabela 1. Parâmetros descritivos das propriedades leiteiras da microrregião de Lavras, MG, 2004.

\begin{tabular}{ccc}
\hline \multirow{2}{*}{ Característica } & \multicolumn{2}{c}{ Média \pm dp(Mínimo - Máximo) } \\
\cline { 2 - 3 } & Grupo A & Grupo B \\
\hline Área da propriedade $(h a)$ & $108,8^{\mathrm{a}} \pm 85,5$ & $490,4^{\mathrm{b}} \pm 530,1$ \\
& $(21-300)$ & $(110-1.500)$ \\
Número médio de vacas & $32,8^{\mathrm{a}} \pm 12,3$ & $128,5^{\mathrm{b}} \pm 45,1$ \\
em lactação & $(20-62)$ & $(50-205)$ \\
Produção total média de & $557,8^{\mathrm{a}} \pm 212,8$ & $1.988,2^{\mathrm{b}} \pm 721,0$ \\
leite por fazenda/dia & $(250-850)$ & $(1.250-3.800)$ \\
Produção média de leite & $16,7^{\mathrm{a}} \pm 4,8$ & $17,6^{\mathrm{a}} \pm 4$ \\
por vaca/dia & $(8-23)$ &, $9(9-26)$ \\
Intervalo médio entre partos & $13,2^{\mathrm{a}} \pm 1,5$ & $14,0^{\mathrm{a}} \pm 1,4$ \\
(meses) & $(12-16)$ & $(12-17)$ \\
\hline
\end{tabular}

Grupo A: $<1.000$ litros de leite/dia; Grupo B: $>1.000$ litros de leite/dia. Valores seguidos por letras diferentes na linha diferem entre si pelo teste $t$ de Student $(p<0,05)$.

Tabela 2. Caracterização das propriedades leiteiras da microrregião de Lavras, MG, 2004.

\begin{tabular}{|c|c|c|}
\hline \multirow[t]{2}{*}{ Característica } & \multicolumn{2}{|c|}{ Freqüência (\%) } \\
\hline & Grupo A & Grupo B \\
\hline \multicolumn{3}{|l|}{ Tipo de leite produzido } \\
\hline Tipo B & 62,5 & 90,0 \\
\hline Tipo C & 37,5 & 10,0 \\
\hline \multicolumn{3}{|l|}{ Tipo de ordenha } \\
\hline Manual & 12,5 & 0,0 \\
\hline Mecânica & 87,5 & 100,0 \\
\hline \multicolumn{3}{|l|}{ Composição racial do rebanho } \\
\hline Puro & 77,8 & 54,5 \\
\hline Mestiço & 22,2 & 18,2 \\
\hline Ambos & 0,0 & 27,3 \\
\hline \multicolumn{3}{|l|}{ Tipo de criação dos animais } \\
\hline Semi-intensivo & 75,0 & 70,0 \\
\hline Intensivo & 25,0 & 30,0 \\
\hline \multicolumn{3}{|l|}{ Tipo de alimentação do rebanho } \\
\hline Pasto + concentrado & 77,8 & 54,5 \\
\hline Confinado (concentrado + volumoso no cocho) & 22,2 & 45,5 \\
\hline \multicolumn{3}{|l|}{ Modo de reposição dos animais de descarte } \\
\hline Com animais do próprio rebanho & 88,9 & 90,9 \\
\hline Compra de novos animais & 11,1 & 9,1 \\
\hline \multicolumn{3}{|l|}{ Histórico de aborto } \\
\hline Sim & 75,0 & 90,0 \\
\hline Não & 25,0 & 10,0 \\
\hline \multicolumn{3}{|l|}{ Intervalo entre partos } \\
\hline Até 14 meses & 75,0 & 80,0 \\
\hline Acima de 14 meses & 25,0 & 20,0 \\
\hline
\end{tabular}

Grupo A: <1.000 litros de leite/dia; Grupo B: >1.000 litros de leite/dia. intervalo médio de partos das propriedades dos grupos A e B não apresentaram diferença estatística significativa. Já, características como área da propriedade, número médio de vacas em lactação e produção total média de leite por fazenda e por dia apresentaram diferença significativa.

Embora as propriedades do grupo B tenham uma área ( $h a)$ maior que a do grupo $\mathrm{A}$, em relação à média de produção de litros de leite por vaca/dia, não foi observado diferença estatística significativa entre os dois grupos. Na Tabela 2 observa-se que, independente de pertencer ao grupo $\mathrm{A}$ ou $\mathrm{B}$, as características zootécnicas e de manejo das propriedades são similares. Nas propriedades do grupo B, predomina a produção de leite tipo B com 100\% dos animais sendo ordenhados mecanicamente.

Freqüência e fatores de risco para Neospora caninum em bovinos leiteiros da microrregião de Lavras. Na tabela 3 observam-se as freqüências de vacas reagentes para anticorpos anti- $N$. caninum nas propriedades dos grupos A e B. Estes grupos não diferiram estatisticamente. A freqüência média global de vacas reagentes foi de $91,2 \%$ (510/559), sendo que $100 \%$ das propriedades tiveram animais soropositivos.

Somente o tamanho da propriedade ( $h a$ ) apresentou associação significativa com a freqüência de vacas infectadas por $N$. caninum. De tal forma, que propriedades com menos de 100 ha tiveram 3,25 vezes mais chance de apresentar vacas

Tabela 3. Freqüência de vacas em lactação reagentes para anticorpos anti-Neospora caninum (RIFI) em propriedades leiteiras do grupo A e B da microrregião de Lavras, MG, 2004.

\begin{tabular}{|c|c|c|c|c|c|}
\hline \multirow[t]{2}{*}{ Grupos } & \multirow{2}{*}{$\begin{array}{c}\text { Proprie- } \\
\text { dades }\end{array}$} & \multicolumn{3}{|c|}{ Número } & \multirow{2}{*}{$\begin{array}{l}\text { Freqüên- } \\
\text { cia (\%) }\end{array}$} \\
\hline & & $\begin{array}{c}\text { Total de } \\
\text { animais* } \\
\text { (vacas) }\end{array}$ & $\begin{array}{l}\text { Animais } \\
\text { testados }\end{array}$ & Positivos & \\
\hline \multirow{8}{*}{$\begin{array}{c}\mathrm{A}(<1.000 \text { litros } \\
\text { de leite/dia })\end{array}$} & 1 & $68(30)$ & $32^{\star *}$ & 32 & 100,0 \\
\hline & 2 & $66(41)$ & 34 & 33 & 97,0 \\
\hline & 3 & 138 (69) & 32 & 31 & 96,9 \\
\hline & 4 & $114(51)$ & 32 & 31 & 96,9 \\
\hline & 5 & 131 (48) & 31 & 30 & 96,8 \\
\hline & 6 & 89 (36) & 32 & 30 & 93,7 \\
\hline & 7 & $100(44)$ & 35 & 31 & 88,6 \\
\hline & 8 & $60(40)$ & 34 & 30 & 88,2 \\
\hline \multirow[t]{5}{*}{ Subtotal A } & 8 & 766 (359) & 262 & 248 & $94,6^{a}$ \\
\hline & 9 & 290 (160) & 32 & 32 & 100,0 \\
\hline & 10 & $126(60)$ & 32 & 32 & 100,0 \\
\hline & 11 & 152 (109) & 29 & 29 & 100,0 \\
\hline & 12 & 600 (223) & 33 & 32 & 97,0 \\
\hline \multirow{6}{*}{$\begin{array}{c}\mathrm{B}(>1.000 \text { litros } \\
\text { de leite/dia) }\end{array}$} & 13 & 169 (70) & 32 & 30 & 93,7 \\
\hline & 14 & 307 (159) & 18 & 17 & 94,4 \\
\hline & 15 & 285 (170) & 31 & 29 & 93,5 \\
\hline & 16 & 200 (118) & 25 & 22 & 88,0 \\
\hline & 17 & $500(240)$ & 34 & 27 & 79,4 \\
\hline & 18 & $508(270)$ & 31 & 12 & 38,7 \\
\hline Subtotal B & 10 & 3.137 (1.579) & 297 & 262 & $88,2^{a}$ \\
\hline Total $(A+B)$ & 18 & 3.903 (1.938) & 559 & 510 & 91,2 \\
\hline
\end{tabular}

*Bezerros, novilhas, vacas e touros.

**nclusão de duas novilhas prenhas.

RIFI= Reação de imunofluorescência indireta.

Valores seguidos por letras iguais na coluna não diferem entre si pelo teste t de Student $(p>0,05)$. 
com uma média de soropositividade acima de 95\% se comparado com vacas de fazendas com mais de $100 \mathrm{ha}$.

Freqüência de anticorpos anti-Neospora caninum em vacas e fetos de matadouro. A freqüência média global de vacas soropositivas para $N$. caninum foi de 97,2\% (559/575), e em soros fetais foi de 12,7\% (64/503), sendo que 90,6\% (58/ 64) dos fetos positivos possuíam entre cinco a sete meses de idade. A idade média de todos os fetos foi de 188 dias. Não houve diferença significativa entre a média de idade dos fetos soropositivos e negativos para $N$. caninum. A freqüência de títulos de anticorpos anti- $N$. caninum para os 64 soros fetais, em ordem crescente de título, foi de: 25 (20\%), 50 (3\%), 100 (6\%), 200 (8\%), 400 (8\%), e 800 (55\%).

\section{DISCUSSÃO}

Os resultados deste estudo indicam que a infecção por $N$. caninum está amplamente distribuída nos rebanhos da microrregião de Lavras, independente do sistema de produção leiteira. OGAWA et al. (2005), também não observaram diferença significativa entre bovinos soropositivos para $N$. caninum e a produção de leite, no norte do Paraná.

Em rebanhos bovinos do Estado de Minas Gerais, freqüências de sororreagentes a anticorpos anti- $N$. caninum de 6,8\% foram relatadas por Costa et al. (2001), 12,7\%-27,3\% por Melo et al. (2001) e 29,0\% por Ragozo et al. (2003). Esses valores estão bem abaixo dos observados na microrregião de Lavras, cujas freqüências de vacas positivas foram de 94,6\% e 88,4\% para propriedades leiteiras dos grupos A e B, respectivamente.

O fato das fazendas com menos de 100 ha terem maior possibilidade de possuírem vacas infectadas por $N$. caninum pode ser explicado, em parte, pela maior densidade de animais nestas propriedades, situação que favoreceria a transmissão horizontal dentro do rebanho; embora esta via seja reconhecida como uma rota secundária de infecção (DAVISON et al., 1999). Resultado semelhante ao do presente estudo foi verificado por Corbellini et al. (2006) em rebanhos leiteiros no Rio Grande do Sul. No entanto, estudo realizado no Paraná não observou associação significativa $(\mathrm{p}>0,05)$ entre o tamanho da propriedade e a freqüência de soropositividade para $N$. caninum em bovinos leiteiros (GUIMARÃES Jr. et al., 2004).

Ogawa et al. (2005) e Bañales et al. (2006), ao analisarem os fatores de risco para $N$. caninum em rebanhos leiteiros no Brasil (Paraná) e Uruguai, respectivamente, não encontraram nenhuma associação significativa entre a soropositividade para $N$. caninum e as variáveis relacionadas ao manejo, ao tamanho do rebanho, a produção de leite, aos problemas reprodutivos, a alimentação, e a presença de cães ou de outros animais na propriedade.

Porém, as amostras estudadas na microrregião de Lavras eram compostas apenas de rebanhos produtores de leite B e C. Portanto, sugere-se que para identificar os fatores de ris- co relacionados ao manejo, a amostra deveria ser constituída por propriedades com caracterizações mais discrepantes, além de animais com problemas reprodutivos, mais velhos e outros.

A freqüência média global de vacas infectadas por $N$. caninum, que foram abatidas no matadouro de Campo Belo, sugere que este protozoário está amplamente distribuído entre fazendas dos municípios de Carvalhos, Campo Belo, Campos Gerais, Ilicínia, Três Corações, Cordislândia, Nepomuceno e Boa Esperança. Esse resultado pode ser explicado, em parte, pelo fato das propriedades localizadas nesses municípios e que periodicamente enviam animais para o abate, possivelmente, possuírem práticas de manejo semelhantes e apresentarem fatores de risco comuns (idade dos animais e presença de cães, entre outros) que favorecem o estabelecimento da infecção por $N$. caninum nesses rebanhos.

A freqüência de vacas soropositivas obtida no presente estudo está bem acima da relatada por Costa et al. (2001), que foi de $16,8 \%$ de animais reagentes para $N$. caninum, analisando 600 amostras de soros coletadas de fêmeas bovinas em matadouro, e oriundas dos municípios de Pirangi, Votuporanga, Guairá e Ituverava no Estado de São Paulo, e das localidades de Iturama e Gurinhatã no Estado de Minas Gerais.

A alta freqüência de vacas reagentes no presente estudo deve-se, possivelmente, ao fato de que a maioria era composta de mestiços leiteiros e com idade avançada. Portanto, esse grupo dentro do rebanho é o que corre maior risco de apresentar anticorpos anti- $N$. caninum, em função da maior oportunidade de transmissão horizontal pela ingestão de oocistos esporulados presentes no ambiente (DUBEY, 1999). Nos EUA, Sanderson et al. (2000) observaram maior freqüência de bovinos infectados por $N$. caninum com o aumento da idade dos animais. Resultado semelhante foi verificado em estudo realizado no Brasil em fêmeas bovinas acima de 24 meses de idade, que apresentaram maior prevalência de soropositividade, indicando que a idade dos animais é um importante fator de risco para a infecção por $N$. caninum (GUIMARÃES Jr. et al., 2004).

No presente estudo, a taxa média global de anticorpos anti$N$. caninum em vacas abatidas no matadouro de Campo Belo (97,2\%), ficou próxima do valor médio global observado em rebanhos leiteiros da microrregião de Lavras (91,2\%). Esse resultado demonstra uma coerência entre os dois estudos, pois parte das vacas leiteiras abatidas no frigorífico de Campo Belo (considerado "fim de linha" destes animais) pertencem a propriedades localizadas em municípios que integram a microrregião de Lavras, sul de Minas Gerais.

A taxa de infecção por $N$. caninum em soros fetais coletados no matadouro de Campo Belo foi de 12,7\% (64/ 503), estando abaixo da relatada por Venturini et al. (1999), na Argentina, que encontraram 20,2\% (21/104) de animais soropositivos, também em fetos coletados em matadouro e utilizando a RIFI. No presente estudo, a baixa freqüência de anticorpos anti- $N$. caninum em soros fetais, se comparada com outros estudos, pode ser explicada, em parte, pela possibili- 
dade da maioria dos fetos serem oriundos de vacas com idade avançada, que foram enviadas para abate, provavelmente pela baixa produção de leite ou problemas reprodutivos. Estudos desenvolvidos em rebanhos leiteiros na Costa Rica (ROMERO et al., 2002) e na Alemanha (DIJKSTRA et al., 2003), demonstraram que a taxa de infecção congênita por $N$. caninum diminui com o aumento do número de gestações e conseqüentemente, com a idade das vacas. Segundo os mesmos autores, a imunidade adquirida atenua a possibilidade de recrudescência da infecção, reduzindo a taxa de transmissão vertical do N. caninum.

Nos fetos soropositivos para $N$. caninum foi observado que 55\% apresentaram título igual 1:800, sugerindo infecção ativa, e que provavelmente esses animais estavam entrando em contato pela primeira vez com o parasito. Embora com baixa freqüência, a presença de anticorpos específicos anti$N$. caninum em soros fetais coletados em matadouro, sugere que novos estudos nessa região são necessários para determinar qual a participação deste parasito nos casos de abortamento e infertilidade em vacas de rebanhos leiteiros da microrregião de Lavras, sul de Minas Gerais.

\section{CONCLUSÕES}

A infecção por $N$. caninum está amplamente distribuída em propriedades produtoras de leite localizadas em municípios da microrregião de Lavras, sul de Minas Gerais. A presença de anticorpos anti- $N$. caninum em soros de fetos coletados em matadouro indica que a avaliação para $N$. caninum deve ser incluída no diagnóstico diferencial nos casos de abortamento em bovinos oriundos de propriedades localizadas em municípios da microrregião de Lavras.

\section{REFERÊNCIAS BIBLIOGRÁFICAS}

ANTUNES, F. Caracterização climática do Estado de Minas Gerais. Informe Agropecuário, v. 12, n. 1-3, p. 9-13, 1986. BAÑALES, P.; FERNANDEZ, L.; REPISO, M.V.; GIL, A.; DARGATZ, D.A.; OSAWA, T. A nationwide survey on seroprevalence of Neospora caninum infection in beef cattle in Uruguay. Veterinary Parasitology, v. 139, n. 1-3, p. 1520, 2006.

CENTRO PANAMERICANO DE ZOONOSIS. Procedimientos para estudios de prevalencia de enfermidades cronicas en el Ganado. Buenos Aires: Ramos Mejia, 1973. 35p. (Nota Técnica, 18).

CORBELLINI, L.G.; SMITH, D.R.; PESCADOR, C.A.; SCHMITZ, M.; CORREA, A.; STEFFEN, D.J.; DRIEMEIER, D. Herd-level risk factors for Neospora caninum seroprevalence in dairy farms in southern Brazil. Preventive Veterinary Medicine, v. 74, n. 2-3, p. 130-141, 2006.

COSTA, G.H.N.; CABRAL, D.D.; VARANDAS, N.P.; SOBRAL, E.A.; BORGES, F. A.; CASTAGNOLLI, K.L. Freqüência de anticorpos anti-Neospora caninum e antiToxoplasma gondii em soros de bovinos pertencentes aos estados de São Paulo e Minas Gerais. Semina, v. 22, n. 1, p. 61-66, 2001.

DAVISON, H.C.; OTTER, O.; TREES, A.J. Estimation of vertical and horizontal transmission parameters of $N$. caninum in dairy cattle. International Journal for Parasitology, v. 29, n. 10, p. 1683-1689, 1999.

DIJKSTRA, TH.; BARKEMA, H.W.; EYSKER, M.; BEIBOER, M.L.; WOUDA, W. Evaluation of a single serological screening of dairy herds for Neospora caninum antibodies. Veterinary Parasitology, v. 110, n. 3-4, p. 161169, 2003.

DUBEY, J.P.; CARPENTER, J.L.; SPEER, C.A.; TOPPER, M.J.; UGGLA, A. Newly recognized fatal protozoan disease of dogs. Journal of the American Veterinary Medical Association, v. 193, n. 9, p. 1269-1285, 1988.

DUBEY, J.P.; LINDSAY, D.S. A review of Neospora caninum and neosporosis. Veterinary Parasitology, v. 67, n. 1-2, p. 1-59, 1996.

DUBEY, J.P. Neosporosis in cattle: biology and economic impact. Journal of the American Veterinary Medical Association, v. 214, n. 8, p. 1160-1163, 1999.

DUBEY, J.P.; SCHARES, G. Diagnosis of bovine neosporosis. Veterinary Parasitology, v. 140, n. 1-2, p. 1-34, 2006.

GUIMARÃES Jr., J.S.; SOUZA, S.L.P.; BERGAMASCHI, D.P.; GENNARI, S.M. Prevalence of Neospora caninum antibodies and factors associated with their presence in dairy cattle of the north of Paraná state, Brazil. Veterinary Parasitology, v. 124, n. 1-2, p. 1-8, 2004.

INSTITUTO BRASILEIRO DE GEOGRAFIA E ESTATÍSTICA - IBGE. 2004. Produção da Pecuária Municipal. Disponível em: <ftp:\|ftp.ibge.gov.br/Produção Pecuária/ Produção da Pecuária Municipal\%5Banual\%5D/2004/> . Acesso em 20 nov. 2006.

MADRUGA, C.R.; ARAÚJO, F.R.; SOARES, C.O. Imunodiagnóstico em Medicina Veterinária. Campo Grande: Embrapa Gado de Corte, 2001. 360p.

MELO, C.B.; LEITE, R.C.; SOUZA, G.N.; LEITE, R.C. Freqüência de infecção por Neospora caninum em dois diferentes sistemas de produção de leite e fatores predisponentes à infecção em bovinos em Minas Gerais. Revista Brasileira de Parasitologia Veterinária, v. 10, n. 2, p. 67-74, 2001.

MOORE, D.P. Neosporosis in South America. Veterinary Parasitology, v. 127, n. 1, p. 87-97, 2005.

OGAWA, L.; FREIRE, R.L.; VIDOTTO, O.; GONDIM, L.F.P.; NAVARRO, I.T. Ocurrence of antibodies to Neospora caninum and Toxoplasma gondii in dairy cattle from the northern region of the Paraná State, Brazil. Arquivo Brasileiro de Medicina Veterinária e Zootecnia, v. 57, n. 3, p. 312-316, 2005.

RAGOZO, A.M.A.; PAULA, V.S.O.; SOUZA, S.L.P.; BERGAMASCHI, D.P.; GENNARI, S.M. Ocorrência de anticorpos anti-Neospora caninum em soros bovinos procedentes de seis estados brasileiros. Revista Brasileira de Parasitologia Veterinária, v. 12, n. 1, p. 33-37, 2003. 
ROBERTS, J.S. Obstetricia Veterinaria y Patologia de la Reproducion. Buenos Aires: Ed. Hemisfério Sur, 1984. 1021p.

ROMERO, J.J.; PEREZ, E.; DOLZ, G.; FRANKENA, K. Factors associated with Neospora caninum serostatus in cattle of 20 specialized Costa Rican dairy herds. Preventive Veterinary Medicine, v. 53, n. 4, p. 263-273, 2002.

SANDERSON, M.W.; GAY, J.M.; BASZLER, T.V. $N$. caninum seroprevalence and associated risk factors in beef cattle in the northwestern United States. Veterinary Parasitology, v. 90, n. 1-2, p. 15-24, 2000.

VENTURINI, M.C.; VENTURINI, L.; BACIGALUPE, D.; MACHUCA, M. Neospora caninum - infections in bovine foetuses and dairy cows with abortions in Argentina. International Journal for Parasitology, v. 29, n. 10, p. 17051708, 1999.

Recebido em 18 de janeiro de 2007.

Aceito para publicação em 20 de dezembro de 2008. 